\title{
Assessment of Soil Degradation and Agricultural Land Suitability for Sustainable Land Management in Alexandria and El-Behiera Governorates, Egypt
}

\author{
Hassan A. Ismail ${ }^{1}$, Osama R. Abd EL-Kawy ${ }^{1}$, Haytham M. Yehia ${ }^{2}$, and \\ Mohamed A. Allam ${ }^{1}$ \\ ${ }^{1}$ Department of Soil and Water Sciences, Faculty of Agriculture, Alexandria University, Egypt. \\ ${ }^{2}$ Soil Salinity and Alkalinity Department, Soil\&water\&environment Institute, Agricultural Research Centre, \\ Ministry of Agriculture, Egypt
}

\begin{abstract}
The old agricultural land in Egypt is under continuous threat by different forms of land degradation, especially chemical degradation. This research aimed to (1) assessing and mapping of soil degradation status in some parts of Alexandria and El-Behiera governorates, (2) addressing causes of soil degradation, and (3) developing a rational agricultural land use options to increase land productivity. Soil and water samples were collected for the assessment of soil degradation and land suitability. Soil degradation was assessed based on the methodology developed by the Food and Agriculture Organization (FAO). Land suitability assessment was performed using the ALESarid-GIS model. Field investigations and results of soil analyses indicated that the major type of land degradation in the study area is the chemical soil degradation (soil salinization and alkalinization) and the main drivers of degradation are the inappropriate land management practices. The results of soil chemical degradation showed that most of the investigated area $(\wedge 9 \%)$ is moderately degraded soil, whereas the low degraded soils covers the remaining area $(11 \%)$. Also, the results indicated that the whole investigated soils have a moderate level of biological degradation, which regards to the moderate level of soil organic matter content. The results from ALESarid-GIS indicated that eighteen crops are considered the most suitable to grow in the investigated area. The suitability classes of these crops vary among highly suitable (S1), moderately suitable (S2) and marginally suitable (S3), but $(\mathrm{S} 1+\mathrm{S} 2)$ of each crop covers more than $72 \%$ of the investigated area. Seven crops can only be grown economically in in the highest levels of soil salinity and alkalinity in the study area, which are alfalfa, wheat, barley, onion, sugar beet, rice and pear, since only these crops are considered highly (S1) and moderately (S2) suitable to be grown in such levels of salinity and alkalinity
\end{abstract}

keywords: soil degradation, sustainable land management, Alexandria and El-Behiera governorates.

\section{INTRODUCTION}

Soil is a valuable non-renewable resource, which provides essential support to ecosystems and exists throughout the world in diverse behavior and properties. Its preservation is vital for food security and the sustainable future (FAO 2015 and Aksoy et al. 2009). According to FAO (2015), about 33\% of the world wide land is moderately to highly degraded land due to various forms of degradation. The current rate of land degradation threatens the capacity of future generations to meet their most basic needs. The sustainable land management is linked to many different areas of sustainable development such as poverty reduction, economic growth and environmental protection. Therefore urgent sustainable land management strategies are required to stop or limit land degradation in its various types.

The old agricultural land in Egypt is under continuous threat by different forms of land degradation. Of the various forms of land degradation, chemical soil degradation is of essence and has been noticed in the irrigated land of the Nile Delta by several soil researchers (Abdel Kawy and Ali 2012, Shalaby et al. 2012, Wahab et al. 2010, Darwish and Abdel Kawy 2008). The main drivers of chemical soil degradation are soil salinization, alkalinization and water logging, which caused by unsustainable land uses and management practices. Soil salinization is the process of accumulation of different salts on or near the soil surface, but the increased content of exchangeable sodium in a soil is referred to as sodification or alkalinization. Salinization and/or alkalinization reduce soil productivity and agricultural production (Kavvadias 2014, Shalaby et al. 2012, and FAO 2009). From this prospective, finding procedure to limit land degradation is an urgent need. The first process of this procedure involves identification and assessment of the land degradation status and the second is establishing a strategy to increase soil productivity and combat soil degradation. Several methodologies have been developed to provide a procedure for land degradation assessment. Such methodologies have been proposed as expert opinion, remote sensing, field monitoring, and productivity measurements as efficient for the assessment of degraded land, but there is no single standardized method for assessment of soil degradation (Tetteh, 2015).

As part of the solution to land degradation is land use planning. Land suitability assessment is considered as an important tool for rational land use 
planning and sustainable land management (Rossiter 1996). Generally, land suitability assessment for agricultural purposes involves characterization of the biophysical and ecological characteristics of an area according to the agricultural potential of the land (Olaniyi et al. 2015).

The objectives of this work are: (a) to assess and map the soil degradation status in some parts of Alexandria and El-Behiera governorates, (b) to address causes of soil degradation, and (c) to develop a rational agricultural land use options based on crop suitability to increase land productivity and limit soil degradation.

\section{MATERIALS AND METHODS}

\section{Study Area:}

The study area locates between $31^{\circ} 07^{\prime}$ to $31^{\circ}$ $20^{\prime}$ North latitudes and $29^{\circ} 51^{\prime}$ to $30^{\circ} 14^{\prime}$ East longitudes (Fig. 1). It is situated within the Northeastern part of Alexandria governorate and the Northwestern part of El-Behiera governorate (Kafr El-Dawar district). It is bounded by the Mediterranean Sea from North, El-Mahmoudia canal from South and West, and Idko and Abo Homos districts from East. It occupies an area of about 28,789 hectares. All of the cultivated land in the study area is under irrigated agriculture. The main water irrigation source is from El-Mahmoudia canal. At present, the cultivated land represents about $63 \%$ of the total study area. Most of the land is flat with elevations range from $-1 \mathrm{~m}$ below sea level to $10 \mathrm{~m}$ above sea level. According to Shata and El Fayoumy (1970) the study area is characterized by the semiarid climate conditions.

2. Field work, laboratory analyses and soil mapping units:

Basing on a 2-km-grid sampling strategy, 49 soil augers were assigned for soil sampling and georeferenced using GPS. Soil auger sampling was only performed for the cultivated land in the study area. A recent land use map, which resulted from supervised classification of 2015 Landsat 8, was used for soil auger sampling (Fig. 2). In the field, locations of soil augers were justified based on services in the study area (i.e. roads, canals, drains, residential areas .... Etc.). Soil samples were collected at successive depths $(30 \mathrm{~cm})$ till water table level or $150 \mathrm{~cm}$ from the soil surface. The fieldwork was carried out during 2014/2015.

Soil auger samples were analyzed in a laboratory with respect to the soil physical and chemical properties. Water irrigation samples were collected from fourteen irrigation canals, and subsequently analyzed. Laboratory analyses were performed using the soil saturation extract method according to Page et al. (1982) and Richards (1954). Soil auger samples and water irrigation samples were dedicated to the production of detailed soil maps, soil mapping units, and crop suitability maps.

Soil salinity, soil alkalinity, and soil depth maps were created through interpolation processes using the Inverse Distance Weighting (IDW) method in ArcGIS $^{\circledR}$ version 9.3 (ESRI 2008). The map of soil units was created through overlay operations. In these operations the above mentioned soil maps were included.

According to the resulted soil mapping units in the study area, a representative soil profile was assigned for each mapping unit. Four soil profiles were dug and sampled in late 2015. According to FAO (1990), the soil profiles were described macromorphologically in the field and then classified according to the American system of soil taxonomy (USDA 2010). Soil profile samples were collected for further physical, chemical and fertility analyses. These samples were dedicated to soil degradation assessment and production of soil degradation maps.

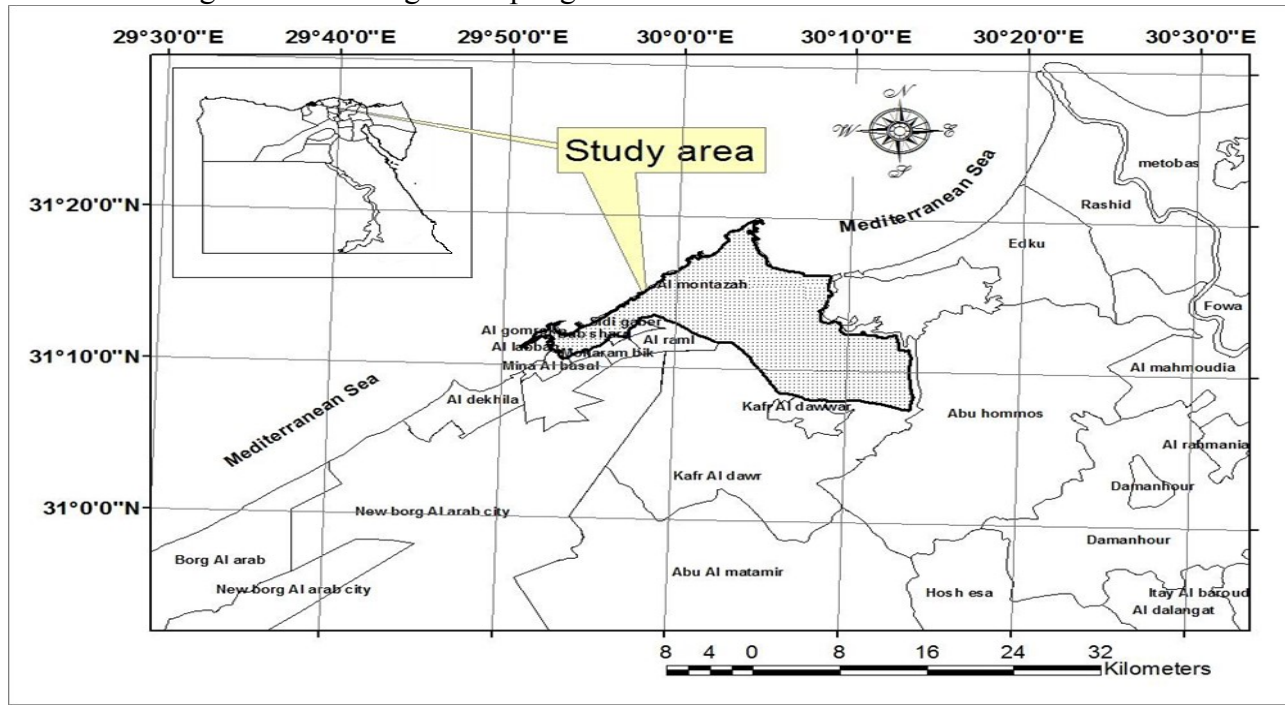

Fig.1: Location map of the study area. 


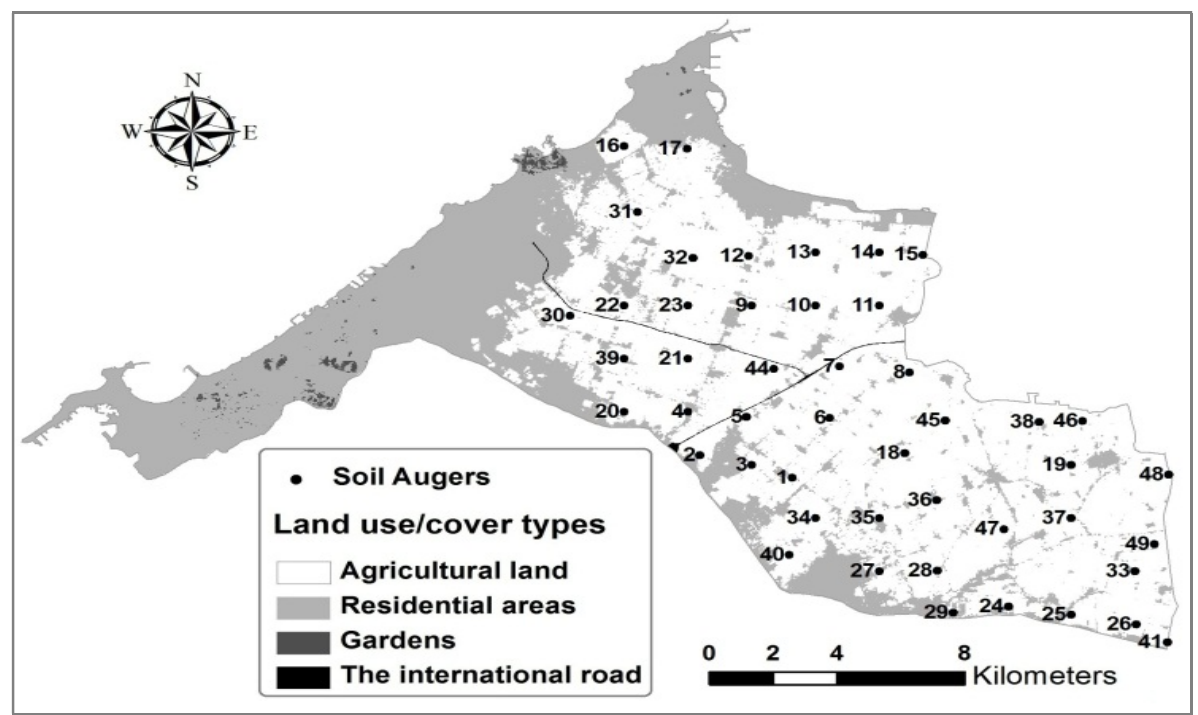

Fig. 2: Soil auger sampling in the study area.

\section{Soil degradation assessment:}

Soil degradation processes are complex, with several interrelations among drivers and properties. Since the use of only one index cannot address degradation status for all this complexity, the degradation status is better represented by an index for each degradation process. However, these indices should be as simple as possible (De Paz et al. 2006 and Moore et al. 1993). Several authors have proposed indices to evaluate soil degradation (Doran and Parkin 1994, Snakin et al. 1996, LopezBermudez and Barbera 1998, and Hess et al. 2000) with different criteria depending on the objectives. We followed the criteria of simplicity and data availability to select the degradation indices. Therefore, chemical and biological soil degradation indices were selected based on the methodology developed by FAO-PNUMA- UNESCO (1980), and applied by Sanchez et al. (1998, 1999) and De Paz et al. (2006) within the Mediterranean region.

-Chemical degradation index (CDI): Under semiarid conditions, soil productivity can be reduced mainly due to salinization or alkalinization. CDI considers both processes into account. A soil under one or both of these processes and with a low cation exchange capacity will correspond to the soils with a higher chemical degradation index whether the cause of degradation is natural or anthropogenic (De Paz et al. 2006). Chemical degradation index was calculated using the following equations:

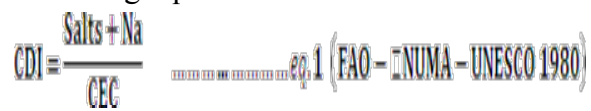

Salts $(\mathrm{meq} / 100 \mathrm{~g})=\left(\begin{array}{lllll}13.5 & \mathrm{X} & \mathrm{EC}_{\mathrm{e}} & \mathrm{X} & \mathrm{Hs}\end{array}\right) / 1000$ .................e eq.2 (De Paz et al. 2006)

$\mathrm{Hs}=28.215+6.09 \mathrm{X} \mathrm{OM}+0.243 \mathrm{X}$ Clay $(\%)-$ 0.11 X Sand (\%) ... eq.3 (De Paz et al. 2006)
Where: Salts is soluble salt content (meq/100g), $\mathrm{Hs}$ is soil water content at saturation $(\%), \mathrm{Na}$ is exchangeable sodium (meq/100g), $\mathrm{EC}_{\mathrm{e}}$ is soil electrical conductivity $(\mathrm{dS} / \mathrm{m}), \mathrm{OM}$ is organic matter content (\%), and CEC is cation exchange capacity (meq/100 g).

- Biological degradation index (BDI): Biological degradation is related to the high decomposition rate of organic matter under semiarid conditions. Organic matter $(\mathrm{OM})$ is one of the main nutrient sources for plants and microorganisms. It affects soil aggregation and prevents crusting (De Paz et al. 2006). BDI considers organic matter content alone as the main factor of biological degradation. Description of the chemical and biological degradation degree was addressed according to the rating assigned in Table (1).

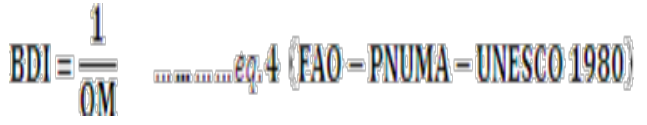

Table 1: Degree and index rating of soil chemical and biological degradation (De Paz et al. 2006).

\begin{tabular}{lcc}
\hline $\begin{array}{l}\text { Degradation } \\
\text { degree }\end{array}$ & $\begin{array}{c}\text { Chemical } \\
\text { degradation } \\
\text { index }\end{array}$ & $\begin{array}{c}\text { Biological } \\
\text { degradation } \\
\text { index }\end{array}$ \\
\hline Very low & $0-0.0081$ & $0-0.3$ \\
\hline Low & $0.0081-0.021$ & $0.3-0.6$ \\
\hline Moderate & $0.021-0.046$ & $0.6-1$ \\
\hline High & $0.046-0.085$ & $1-2.5$ \\
\hline Very high & $>0.085$ & $>2.5$ \\
\hline
\end{tabular}

a. Land suitability assessment

Essentially, land suitability assessment involves accounting for the land attributes and comparing them with the crop requirements in order to develop crop suitability index in a spatially explicit manner 
(Olaniyi et al. 2015). The crop suitability of the cultivated land was assessed by using ALESaridGIS model (Abd Elkawy et al. 2010), where crop suitability indices and classes were calculated based on the average weight data of soil auger analyses and then maps were produced. ALESarid-GIS calculates suitability indices and classes for 27 crops. The assessment is based on crop suitability affected by the environmental potential at the site, such as the physical, chemical and fertility characteristics of the soil, irrigation water quality, and climatic conditions. The latter environmental factors are used to measure the inherent soil-based qualities of land as they relate to the agricultural suitability. Table (2) shows the ratings used by ALESarid-GIS for suitability assessment.

Table 2: Land suitability classes, definition and ranges used by ALESarid-GIS (Abd Elkawy et al. 2010).

\begin{tabular}{lcc}
\hline Class & Definition & Index (\%) \\
\hline S1 & Highly suitable & $80-100$ \\
\hline S2 & Moderately suitable & $60-80$ \\
\hline S3 & Marginally suitable & $40-60$ \\
\hline S4 & Conditionally suitable & $20-40$ \\
\hline NS1 & Potentially suitable & $10-20$ \\
\hline NS2 & Actually unsuitable & $<10$ \\
\hline
\end{tabular}

\section{RESULTS AND DISCUSSION}

\section{Soil and irrigation water characterization:}

Summary statistics of some soil and water irrigation properties in the investigated soil augers and water samples is reported in Table (3). The results indicated that the soil depth ranges from 70 $\mathrm{cm}$ (moderately shallow) to $150 \mathrm{~cm}$ (very deep) with a mean value of $112 \mathrm{~cm}$. The soil $\mathrm{pH}$ values indicate a neutral to slightly alkaline soil conditions, where the $\mathrm{pH}$ value ranges from 7.31 to 8.95 . Soil salinity (EC) values vary between $0.4 \mathrm{dS} / \mathrm{m}$ and $12.1 \mathrm{dS} / \mathrm{m}$ with an average of $1.99 \mathrm{dS} / \mathrm{m}$. Exchangeable sodium percentage (ESP) ranges from 1.29 to 35.33 with an average of 11.11. Clay content has a minimum value of $1.57 \%$, a maximum value of $68.76 \%$, and the average is $36.04 \%$. The prevailing soil texture is clay and sand clay loam. The variation coefficient (CV) of soil $\mathrm{pH}$ has the minimum value $(3.93 \%)$. This hetrogeneity coefficient has an average value of $13.65 \%$ for soil depth, while, it has the maximum values $(41.19 \%, 58.05 \%$, and $73.36 \%)$ for clay content, ESP, and EC, respectively. Salinity of water irrigation varies between $0.5 \mathrm{dS} / \mathrm{m}$ and 2.39 $\mathrm{dS} / \mathrm{m}$ with an average of $1.14 \mathrm{dS} / \mathrm{m}$. Sodium adsorption ratio (SAR) ranges from 1.72 to 8.65 (non alkaline water) taking an average value of 3.84 .

The spatial distribution of soil depth, soil salinity (EC), and soil alkalinity (ESP), as well as their representative areas are displayed in Fig. (3). Only surface layer data of each soil auger was included in map production for salinity and alkalinity. It is obvious that the majority of the investigated soil (89\%) is more than $100 \mathrm{~cm}$ depth, but separated patches of lesser depths $(70-100 \mathrm{~cm})$ are found, representing about $11 \%$ of the cultivated area. Water table level is the limiting factor for soil depth in these patches. Regarding soil salinity, it is evident that an area of about 55\% represents soil salinity less than $2 \mathrm{dS} / \mathrm{m}$ and mainly confined to the Northeast and Southeast parts of the study area. About $42 \%$ of the investigated soil has EC values between $2 \mathrm{dS} / \mathrm{m}$ and $4 \mathrm{dS} / \mathrm{m}$. Soil salinity more than $4 \mathrm{dS} / \mathrm{m}$ is found in small patches in the investigated area representing about $3 \%$. About $96 \%$ of the area has ESP $<15 \%$ (non alkaline soil conditions). The highest ESP values are also found in the most Northern and Southwestern parts in the investigated area.

\section{Soil mapping units and soil degradation:}

Based on the spatial variability of soil salinity, soil alkaninity, and soil depth, four soil units were recognized in the investigated area. As shown in Fig. (4), the non to very slightly saline $(<4 \mathrm{dS} / \mathrm{m})$, non alkaline $(<15)$ and deep to very deep $(100-150$ $\mathrm{cm})$ is the dominant soil unit, which covers most $(83 \%)$ of the study area. The second largest unit is the non to very slightly saline, non alkaline and moderately shallow $(70-100 \mathrm{~cm})$. It occupies $11 \%$ of the investigated soils and distributes in small patches all over the investigated area. The non to very slightly saline, alkaline $(>15)$ and deep to very deep unit represents $3 \%$ of the investigated area and allocates in small patches in the Northern and Southeastern parts of the area. The slightly to moderately saline $(>4 \mathrm{dS} / \mathrm{m})$, non alkaline and deep to very deep soil unit concentrates in the Eastern part of the study area and represents $3 \%$ of the investigated area. Variation among soil units is a result of different agricultural management practices and human activities.

The key of soil taxonomy (USDA, 2010) was applied to classify the representative soil profiles, in this system soil great groups are defined according to the morphological properties of the investigated soil profiles and the features associated with certain genetic factors such as, presence or absence of major diagnostic horizons, soil moisture regime, parent material, soil structure, soil texture, and other specific soil physical and chemical properties. The investigated soil profiles are weakly developed and reflect the prevailing dry climatic conditions, Torric moisture regime, and the dominant Flavo-lacustrine parent material. The only observed diagnostic horizon is Ochric epipedon. Accordingly, the soil could be classified as Torrifluvents and Typic torrerts soil great groups. The soil mapping units and their soil taxonomy are displayed in Table (4). 
Table. 3: Summary statistics of some soil and water irrigation properties

\begin{tabular}{lccccccc}
\hline \multirow{2}{*}{ Statistical parameters } & \multicolumn{3}{c}{ Soil } & \multicolumn{3}{c}{ Water irrigation } \\
\cline { 2 - 8 } & $\begin{array}{c}\text { Depth } \\
(\mathbf{c m})\end{array}$ & $\mathbf{p H}$ & $\begin{array}{c}\text { EC } \\
\mathbf{( d S / m )}\end{array}$ & $\mathbf{E S P}$ & $\mathbf{p H}$ & $\begin{array}{c}\text { EC } \\
(\mathbf{d S} / \mathbf{m})\end{array}$ & SAR \\
\hline Minimum & 70.00 & 7.31 & 0.40 & 1.29 & 1.57 & 6.50 & 0.50 \\
\hline Maximum & 150.00 & 8.95 & 12.10 & 35.33 & 68.76 & 8.20 & 2.39 \\
\hline Mean & 112.00 & 8.14 & 1.99 & 11.11 & 36.04 & 7.24 & 1.14 \\
\hline Range & 80.00 & 1.64 & 11.70 & 34.04 & 67.20 & 1.52 & 1.89 \\
\hline Standard Deviation & 15.29 & 0.32 & 1.46 & 6.45 & 14.85 & 0.45 & 0.57 \\
\hline CV\% & 13.65 & 3.93 & 73.36 & 58.05 & 41.19 & 6.21 & 50.0 \\
\hline
\end{tabular}

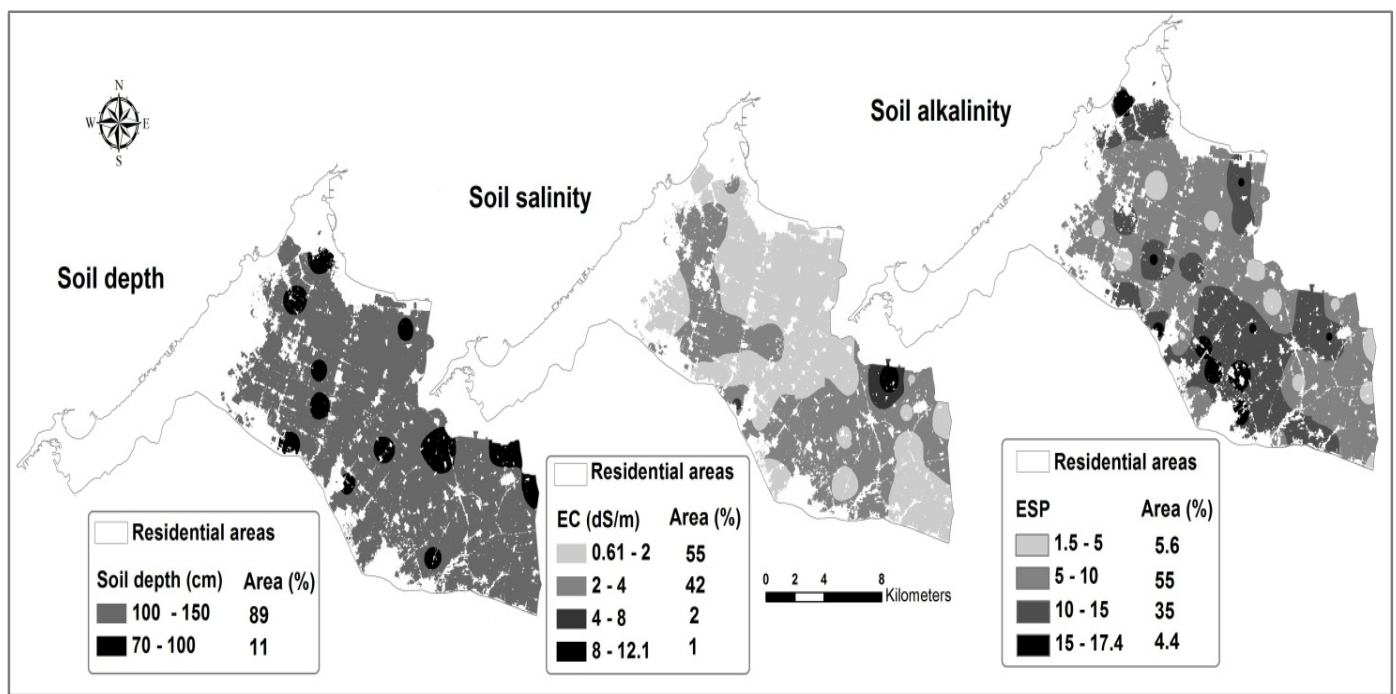

Fig. 3: Distribution of soil depth, soil salinity, and soil alkaline in the study area.

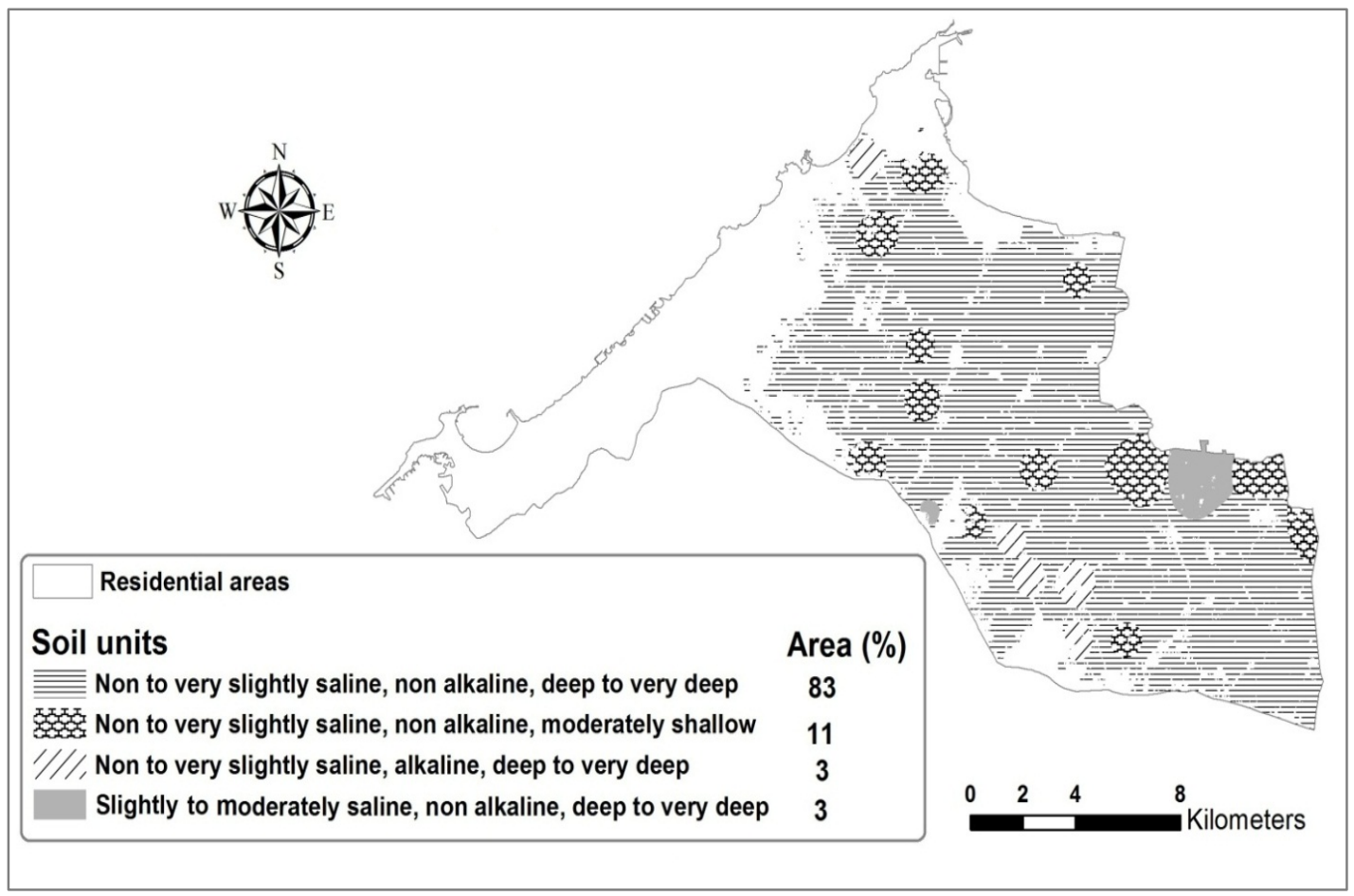

Fig. 4: Distribution soil mapping units in the study area. 
Table 4: The soil mapping units and their soil taxonomy.

\begin{tabular}{|c|c|}
\hline Soil units & Soil taxonomy \\
\hline Non to very slightly saline, non alkaline, deep to very deep & Torrifluvents \\
\hline Non to very slightly saline, non alkaline, moderately shallow & Torrifluvents \\
\hline Non to very slightly saline, alkaline, deep to very deep & Typic Torrerts \\
\hline Slightly to moderately saline, non alkaline, deep to very deep & Typic Torrerts \\
\hline
\end{tabular}
of soil degradation. A correlation analysis was performed in order to identify the most influential variables controlling the CDI for the investigated soils. In this analysis, the selected variables (soluble salts, exchangeable sodium and CEC) were varied within a particular range, and the effect on CDI was addressed. The results in Figs (5 and 6) revealed a strong correlation $(\mathrm{r}=0.99$ and 0.95$)$ between CDI on one side and the soluble salt content and the exchangeable sodium on the other side, respectively. A moderate correlation $(\mathrm{r}=0.57)$ was observed between CDI and CEC. This means that slight variations in the soluble salt content and the exchangeable sodium lead to a remarkable change in the chemical degradation degree. The high effect of the soluble salts content and exchangeable sodium on CDI could be regarded to their high levels which cannot be buffered by CEC, since the high salt content in general and the high sodium content in particular affect the soil hydraulic properties and increase the rate of soil salinization and alkalinization.

The results of soil chemical degradation showed that the CDI levels vary from low (0.0156) to moderate $(0.045)$. The spatial extent of chemical degradation degrees is depicted in Fig. (7), where $11 \%$ of the investigated area is low degraded soil $(\mathrm{CDI}=0.0156)$ and this area is represented by the soil unit "non to very slightly saline, non alkaline, and moderately shallow". On the other hand, most of the investigated area $(89 \%)$ is moderately degraded soil (CDI from 0.032 to 0.045 ) and this area is represented by the remaining soil units.

Also, the results showed that the whole investigated soils have a moderate level of biological degradation (Fig. 7), where BDI ranges from 0.6 to 0.89 . This level of degradation regards to the moderate organic matter content, which varies between 1.1 to $1.7 \%$. However the soil of the study area has been cultivated for a long term, but the semiarid conditions of the area could explain the high rate of organic matter decomposition.

Field inspections and soil analyses indicate that the major type of land degradation in the study area is the chemical soil degradation (soil salinization and alkalinization) and the causes of land degradation are the inappropriate land management practices, where several farmers sometimes use drainage water as a source of irrigation. The salinity

\section{Land suitability assessment:}

Generally, results from ALESarid-GIS indicate that eighteen crops are considered the most suitable to grow in the investigated area because their $(\mathrm{S} 1+\mathrm{S} 2)$ represents more than $72 \%$ of the cultivated land in the study area for each crop. Meanwhile, $(\mathrm{S} 1+\mathrm{S} 2)$ for the remaining nine crops represents less than $28 \%$ of the investigated area and these crops are considered marginally suitable (S3) for more than half of the area for each crop. According to the results, the most suitable crops to grow in the investigated area can be categorized into two categories. Category I includes alfalfa, wheat, barley, onion, sugar beet and rice (in the order indicated), where S1 for each crop represents more than $64 \%$ of the investigated area. Category II includes sunflower, cotton, pea, sorghum, cabbage, pear, maize, watermelon, fababean, pepper, soybean and apple (in the order indicated), where S1 for each crop represents less than $14 \%$ of the investigated area. The suitability maps for the most suitable crops and their representative areas are presented in Figs. $(8,9,10$, and 11).

The dominant limiting parameter for crop suitability of most crops is the soil hydraulic conductivity. It has a slight effect on wheat and barley. The exchangeable sodium percent (ESP) is the second most limiting parameter for sugar beet, fababean, soybean, maize, watermelon, sorghum, and pear suitability. Ground water depth slightly affects the fruits suitability in the investigated area. ALESarid-GIS assigned these parameters as limiting factors because their index values are less than $50 \%$.

Based on the spatial extent of soil salinity and alkalinity (Fig. 3) and the spatial distribution of crop suitability (Figs. 8, 9, 10, and 11), it is noticeable that the crops which can be grown economically in the highest levels of salinity and alkalinity in the study area are alfalfa, wheat, barley, onion, sugar beet, rice and pear, since only these crops are considered highly (S1) and moderately (S2) suitable to be grown in such levels of salinity and alkalinity.

Such kind of assessment allowed identifying the main limiting factors for the agricultural production and enabled developing an agricultural land use options able to increase the land productivity. 

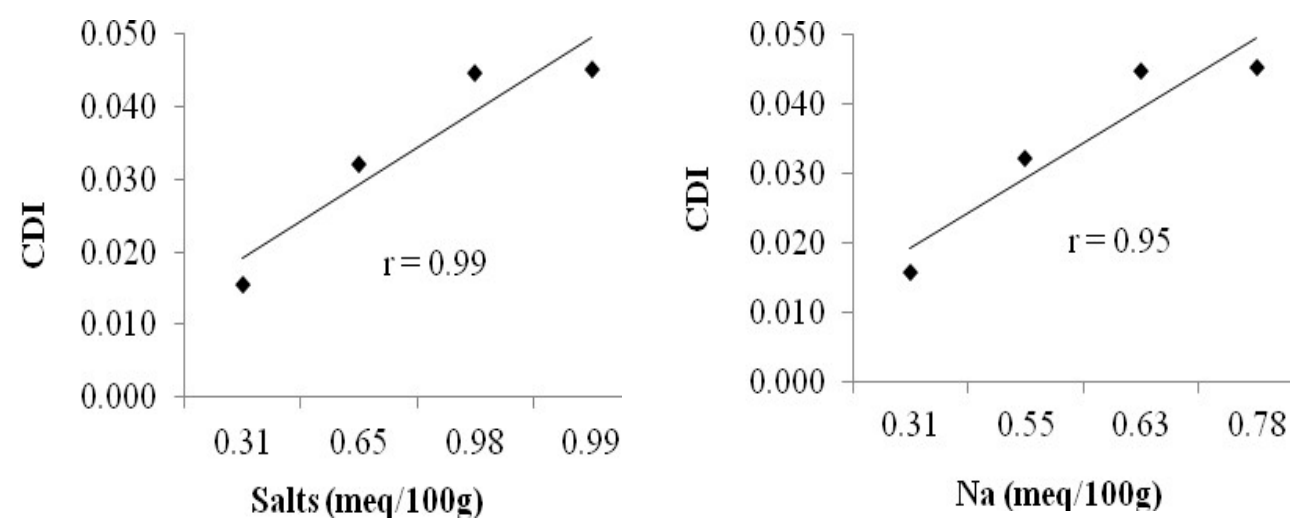

Fig. 5: Effects of soluble salts content and exchangeable sodium on CDI.

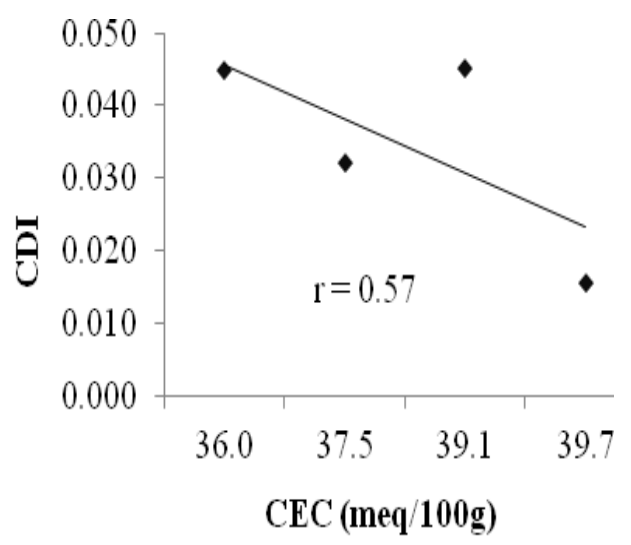

CE

C

Fig. 6: Effect of cation exchange capacity on CDI

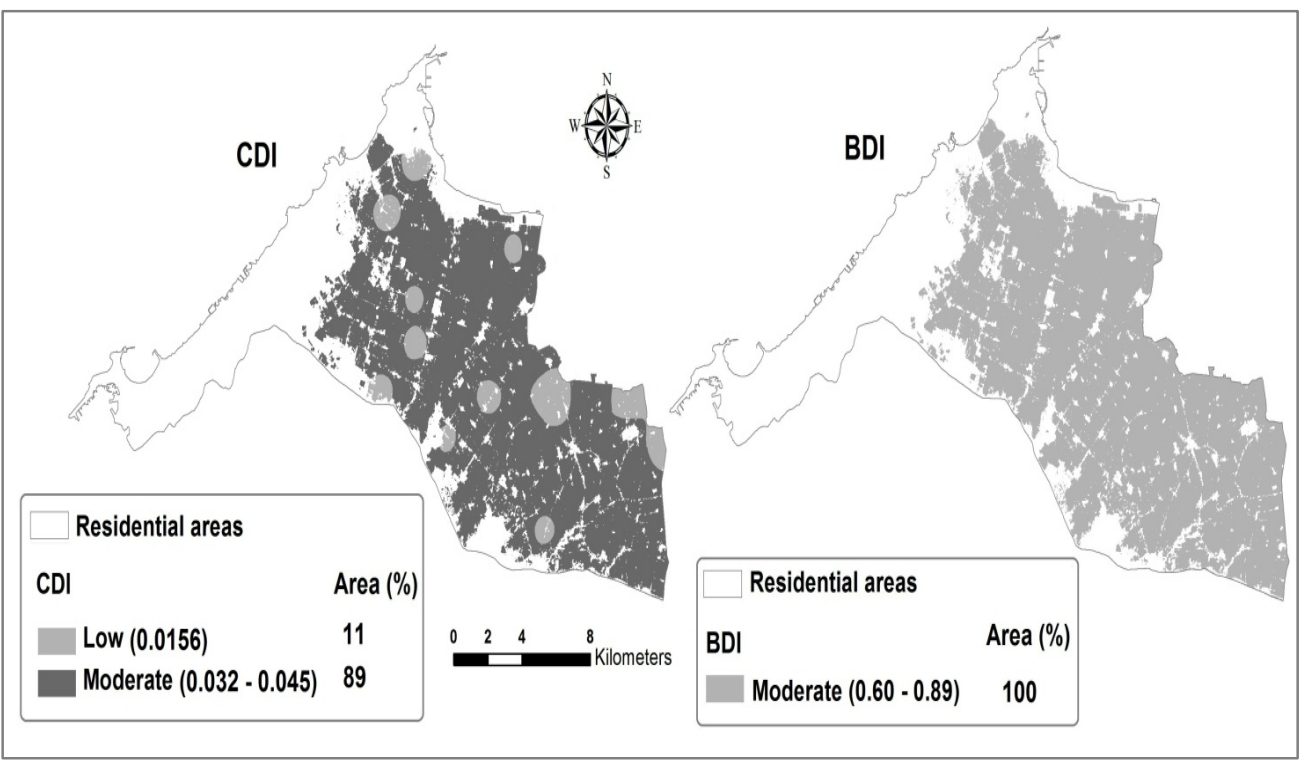

Fig. 7: Chemical (CDI) and biological (BDI) degradation status in the study area. 


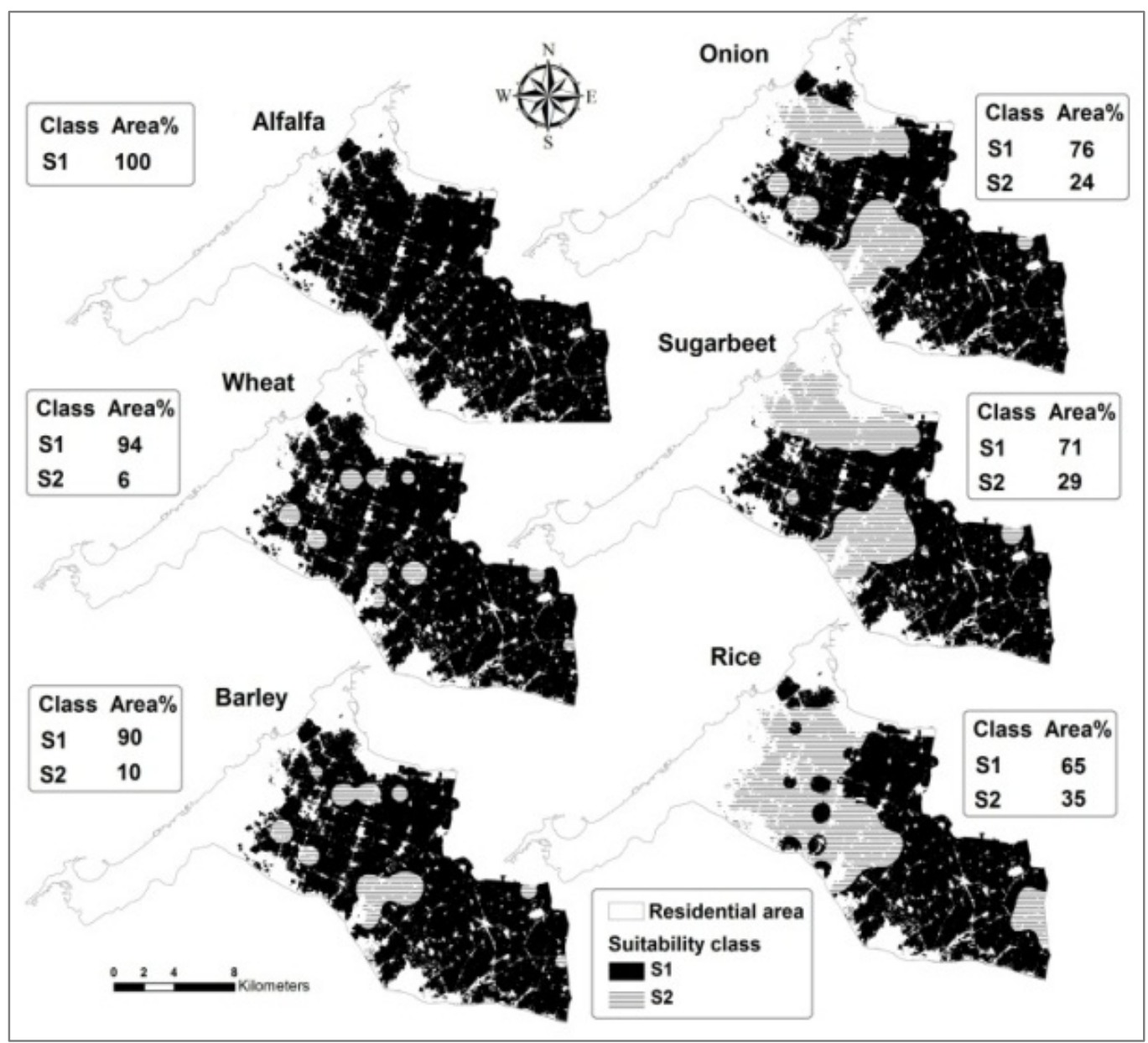

Fig. 8: Spatial distribution of suitability classes for the most suitable field crops (Category I).

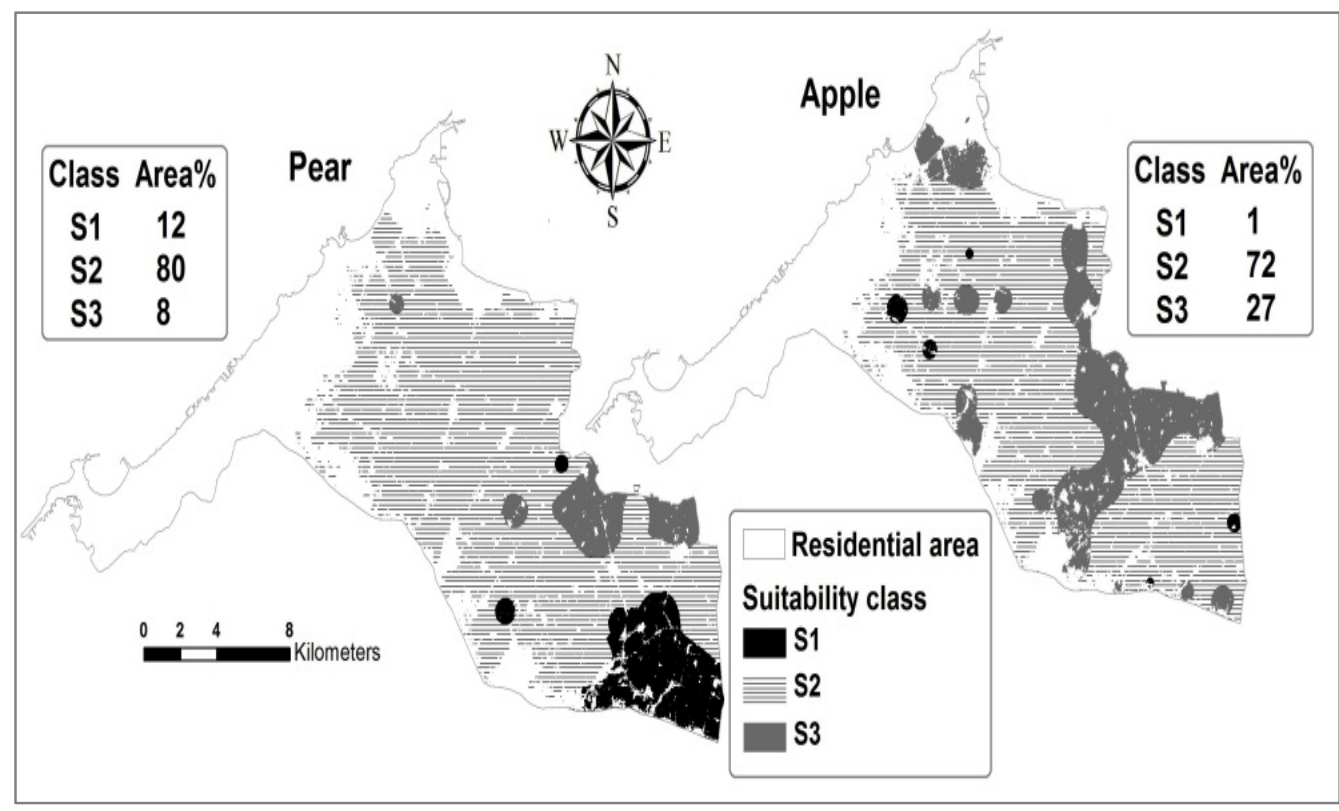

Fig. 9: Spatial distribution of suitability classes for the most suitable fruit trees (Category II). 


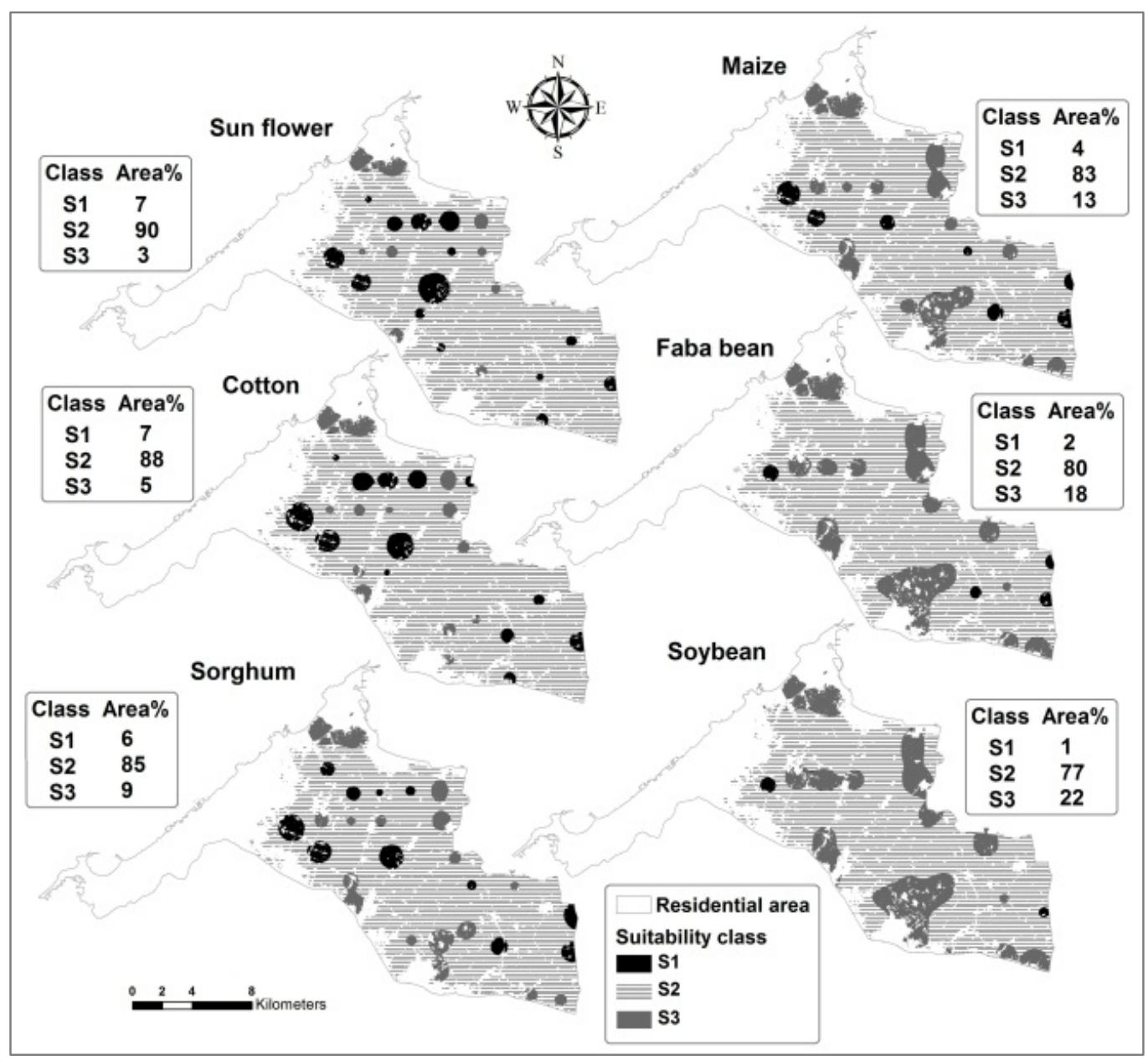

Fig. 10: Spatial distribution of suitability classes for the most suitable field crops (Category II).

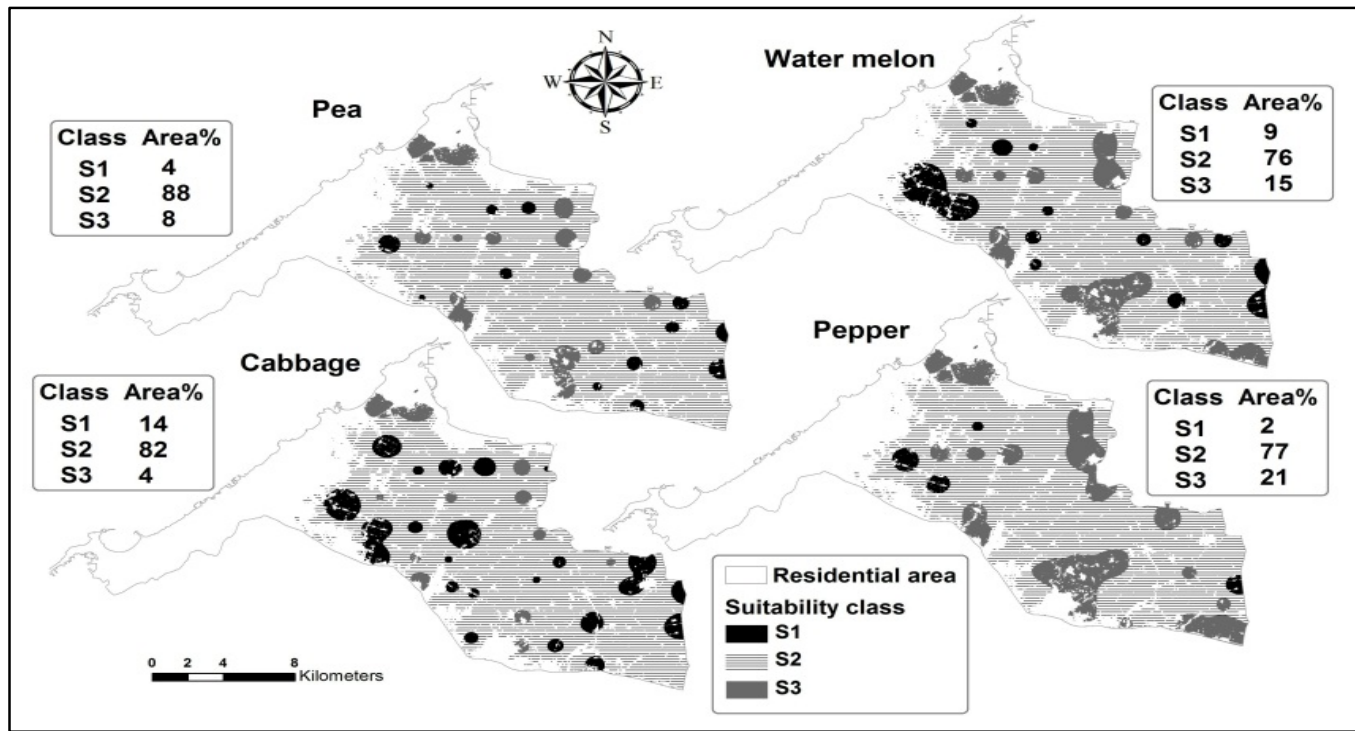

Fig. 11: Spatial distribution of suitability classes for the most suitable vegetable crops (Category II). 


\section{CONCLUSION}

According to the methodologies followed in this research, it can be concluded that a significant portion $(89 \%)$ of the investigated area is under the moderate level of chemical soil degradation. In contrast, the low degraded soils cover the remaining area $(11 \%)$. The moderate level of soil degradation may be regard to the inappropriate land management practices in the study area. Also, the whole investigated soils have a moderate level of biological degradation, which regards to the moderate level of soil organic matter content.

This study found that eighteen crops are considered the most suitable to grow in the investigated area. The suitability classes of these crops vary among highly suitable (S1), moderately suitable (S2) and marginally suitable (S3), but $(\mathrm{S} 1+\mathrm{S} 2)$ of each crop covers more than $72 \%$ of the investigated area. Seven crops can only be grown economically in in the highest levels of salinity and alkalinity in the study area, which are alfalfa, wheat, barley, onion, sugar beet, rice and pear. Since only these crops are considered highly (S1) and moderately (S2) suitable to be grown in such levels of salinity and alkalinity. Such kind of assessment allowed identifying the main limiting factors for the agricultural production and enabled developing an agricultural land use options able to increase the land productivity.

This research results in land resources management will serve as a scientific basis for appropriate land use planning to ensure a sustainable land management and future land use planning.

\section{REFERENCES}

Abd El-Kawy, O.R., Ismail, H.A., Rød. J.K., and Suliman, A.S. (2010). A Developed GIS-based Land Evaluation Model for Agricultural Land Suitability Assessments in Arid and Semi Arid Regions. Research Journal of Agricultural and Biological Sciences, 6 (5); 589-599

Abdel Kawy, W., A., and Ali, R.R. (2012). Assessment of soil degradation and resilience at northeast Nile Delta, Egypt: The impact on soil productivity. The Egyptian Journal of Remote Sensing and Space Sciences. 15, 19-30

Aksoy, E., Ozsoy G., and M. Dirim S. (2009). Soil mapping approach in GIS using Landsat satellite imagery and DEM data. African Journal of Agricultural Research. 4 (11), pp. 1295-1302.

Darwish Kh. And Abde 1 Kawy W. A. (2008). Quantitive Assessment of Soil Degradation in some Areas North Nile Delta, Egypt. International Journal of Geology. 2(2), pp 1722.
De Paz, J.M., Sanchez, J., Visconti, F. (2006). Combined use of GIS and environmental indicators for assessment of chemical, physical and biological soil degradation in a Spanish Mediterranean region; Journal of Environmental Management, 79, 150-162.

Doran, J.W., and Parkin, T.B. (1994). Defining and assessing soil quality. In: Doran, J.W., Coleman, D.C., Bezdicek, D.F., Stewart, B.A. (Eds.), Defining soil quality for sustainable environment. Soil Sci.Soc. Am. Special publication N. 35, Madison, Wisconsin, US, pp. $3-21$.

ESRI (2008). Arc-GIS 9.3, 3D analyst. Redlands, CA, USA.

FAO (2015). Soil is a non-renewable resource. 2015 international year of soils. Food and Agriculture Organization. Rome, Italy. http://www.fao.org/3/a-i4373e.pdf

FAO (2009). Advances in the assessment and monitoring of salinization and status of biosaline agriculture. Food and Agriculture Organization. Rome, Italy.

FAO (1990). Guidelines for soil profile description. 3rd ed., FAO, Rome.

FAO, PNUMA, UNESCO (1980). Metodologi'a provisional para la evaluación de la degradacio'n de los suelos. FAO, Rome.

Halm D, Grathwohl P. (2005). Integrated Soil and Water protection against diffuse pollution. Geophys. Res. 7: 05086.

Hess, G.R., Lee, C., Fiscus, D.A., Hellkamp, A.S., McQuaid, B.F., Munster, M.J., Peck, S.L., and Shafer, S.R. (2000). A conceptual model and indicators for assessing the ecological condition of agricultural lands. J.Environ. Qual. 29, 728 737.

Kavvadias V. (2014). Soil degradation. Soil science institute of Athens-National Agricultural Research Foundation.

Lopez-Bermudez, F., and Barbera, G.G. (1998). Indicators of degradation in semiarid mediterranean agroecosystem of southeastern Spain, Proceedings of the International Seminar of Indicators for Assessing Desertification in the Mediterranean. Porto Torres, Italy.

Moore, I.D., Turner, A.K., Wilson, J.P., Jenson, S.K., Band, L.E. (1993). GIS and land-surfacesubsurface process modeling. In: Goodchild, M.F., Goodchild, M.F. (Eds.), Environmental modeling with GIS. Oxford University Press, pp. 196-230.

Olaniyi A., Ajiboye, A.J., Abdullah, A.M., and Sood, A.M. (2015). Agricultural land use suitability assessment in Malaysia. Bulgarian Journal of Agricultural Science, 21 (3), 560572. 
Page, A. L.; Miller, R. H. and Keeny, R. (1982). "Methods of soil analysis. Part2. Chemical and microbiological properties. Agron. Monograph No. 9, ASA, Madison, WI, USA.

Richards, R.L. (ed.), (1954). Diagnosis and improvement of saline and alkaline soils. Agriculture Handbook No. 60, U.S Govt. Printing Office, Washington, USA.

Rossiter, D.G. (1996). A theoretical frame work for land evaluation. Geoderma, 72(3-4): 165-190.

Sanchez, J., Boluda, R., Morell, C., Colomer, J.C., and Artiago, A. (1999). Assessment of soil degradation within the EFEDA area. In: Balabanis, P., Peter, D., Ghazi, A., Sogas, M.T. (Eds.), Mediterranean Desertification: Research Results and Policy Implications, pp. 387-396.

Sanchez, J., Boluda, R., Morell, C., Colomer, J.C., and Artiago, A. (1998). Degradation index of desertification threatened soils in the Mediterranean region. Application in CastillaLa Mancha (Spain). The soil as a strategic resource: degradation processes and conservation measures. Geoforma ediciones, Logrono, Spain pp. 441-448.
Shalaby, A., Ali, R., and Gad, A. (2012). Land Degradation Monitoring in the Nile Delta of Egypt, using Remote Sensing and GIS. International Journal of Basic and Applied Sciences. Vol. 1 No.4. 2012. Pp. 292-303.

Shata, A. A. and El Fayoumy, I. F., (1970). Remarks on the Regional Geological Structure of the Nile Delta. Hydrology of Deltas: proceedings of the Bucharest Symposium., UNESC, Vol. I, pp 189 - 197.

Snakin, V.V., Krechetov, P.P., Kuzovnikova, T.A., Alyabina, I.O., Gurov, A.F., and Stepichev, A.V. (1996). The system of assessment of soil degradation. Soil Techno. 8, 331-343.

Tetteh, R. N. (2015). Chemical soil degradation as a result of contamination: A review. Journal of Soil Science and Environmental Management . Vol. 6(11), pp. 301-308, December, 2015

USDA (2010). United States Department of Agriculture. Keys to Soil Taxonomy. Eleventh Edition. Washington, D.C.

Wahab M. A., Rasheed M. A., and Youssef R. A. (2010). Degradation Hazard Assessment of Some Soils North Nile Delta, Egypt. Journal of American Science. 6(6), pp 156-161. 


\title{
تقييم تلهور التربة ومدى ملائمتها للزر اعة بهدف تحقيق التنمية المستدمة للارض التاض بمحافظتى الاسكندرية و البحيرة، مصر
}

\author{
حسن احمد اسماعيل'، أسامة راضى عبد القوى'، هيثم محمد يحيى'، محمد عبد الراضى علام' الرام

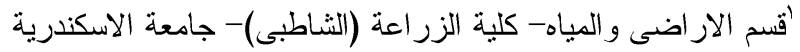

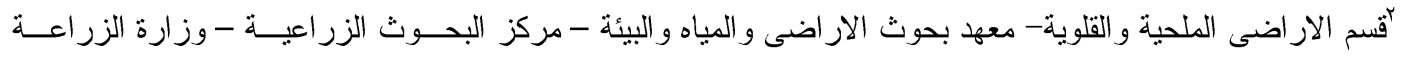

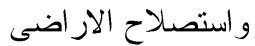

\section{|لملخص العربي}

تتعرض الأر اضي الزراعية القديمة في مصر للتهديد المستمر بالصور المختلفة من التذهور لا سيما التذهور الكيميائي. ومن هذا المنطلق فان هذا البحث يهدف إلى تقييم حالة تدهور التزبة في بعض أجزاء من محافظتي

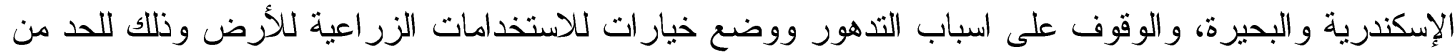
تدهور ها ولزيادة قدتها الاإنتاجية، حيث جمعت عينات من التربة ومياه الرى لهذا الغرض. تم تقييم تدهور التربة

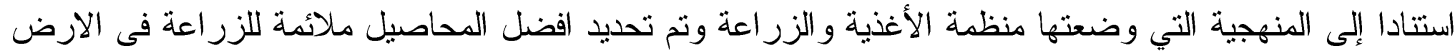
طبقا لظروفها الحالية باستخدام برنامج ALESarid-GIS. حيث اثشارت الملاحظات الميدانية الى جانب تحليلات التربة أن النوع السائد لتدهور التربة في منطقة الدراسة هو التدهور الكيميائي متمثلا فى تملح وصودية التربة، وان الاسباب الرئيسية للتدهور هي الممارسات الزراعية الغير ملائمة لإدارة الأرض. وأظهرت نتائج التدهور الكيميائي للتزبة أن معظم مساحة منطقة الدر اسة (89\%) تقع فى المستوى المتوسط من التدهور بينما المساحة المتبقية (1)

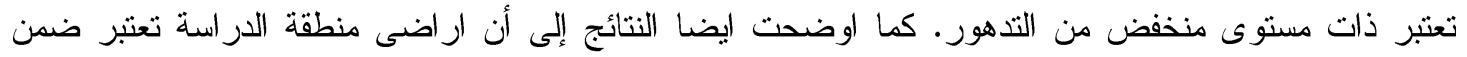
المستوى المتوسط من التدهور الحيوى. وأظهرت نتائج ملائمة المحاصيل للزر اعة بالمنطقة أن ثمانية عشر محصو لا

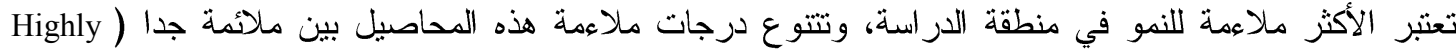
(suitable "S1" و اعتبرت هذه المحاصيل الاكثر ملائمة لان (S1+S2) لكل محصول منها يغطي أكثر من rr\% من مساحة منطقة الدر اسة. و استتادا إلى نمط التوزيع المكانى لملوحة وقلوية التربة وكذلك ملاعمة المحاصيل المختلفىه تبين ان هنالك سبعة محاصيل فقط يمكن زر اعتها اقتصاديا في المستويات العليا من الملوحة و القلوية فى منطقة الدراسة وذللك لان هذه المحاصيل لها درجات عالية (S1) إلى متوسطة (S2) من الملائمة فى مثل هذة المستويات. ويمكن الاستفادة من نتائج هذا البحث فى تحقيق التتمية المستدامة للمو ارد الارضية فى منطقة الدراسة حيث انه ساعد فى طرح خيارات

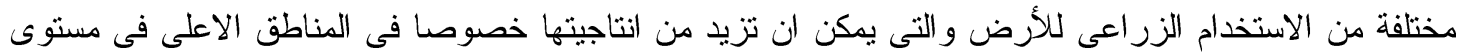
الملوحة و القلوية. 